\begin{tabular}{l|l} 
Jurnal Eksplorasi Akuntansi & ISSN : 2656-3649 (Online) \\
Vol. 2, No 3, Seri A, Agustus 2020, Hal 2893-2911 & http:/jea.ppj.unp.ac.id/index.php/jea/issue/view/25
\end{tabular}

\title{
PENGARUH KEPEMILIKAN ASING, LEVERAGE, CASH HOLDINGS DAN DEBT MATURITY TERHADAP KINERJA KEUANGAN PERUSAHAAN
}

(Studi Empiris pada Perusahaan Property dan Real Estate yang Terdaftar pada Bursa Efek Indonesia Tahun 2014-2018)

\author{
Murti Sari Dewi $^{1}$, Erly Mulyani ${ }^{2}$ \\ 1)Alumni Jurusan Akuntansi Fakultas Ekonomi Universitas Negeri Padang \\ 2) Jurusan Akuntansi Fakultas Ekonomi Universitas Negeri Padang \\ *Korespondensi: murtis871@gmail.com
}

\begin{abstract}
This study aims to examine the effect of foreign ownership, leverage, cash holding and debt maturity on financial performance in property and real estate companies listed on the Indonesia stock exchange (idx) in the period 2014-2018. This study is categorized as causative research. The population in this study are property and real estate companies listed on the Indonesia stock exchange (idx) in the period 2014-2018. By using purposive sampling method, there were 24 companies as the research's sample. The type of data used is secondary data and used is panel regression analysis. The results of this study indicate that foreign ownership, cash holding and debt maturity has no significant effect on financial performance, only leverage has significant effect on financial performance.
\end{abstract}

Keywords: Foreign Ownership; Leverage; Cash Holding; Debt Maturity; and Financial Performance

How to cite (APA $6^{\text {th }}$ style):

Dewi, S. M., \& Mulyani, E. (2020). Pengaruh Kepemilikan Asing, Leverage, Cash Holding, Dan Debt Maturity Terhadap Kinerja Keuangan Perusahaan (Studi Empiris Perusahaan Property dan Real Estate yang Terdaftar di Bursa Efek Indonesia Tahun 2014-2018). Jurnal Eksplorasi Akuntansi. 2(3). Seri A. 2893-2911.

\section{PENDAHULUAN}

Perkembangan bisnis yang semakin pesat, serta perkembangan teknologi yang semakin canggih membuat persaingan bisnis yang ketat antar perusahaan. Jumlah perusahaan yang berdiri dan bergabung dengan dunia bisnis di Indonesia meningkat dari tahun ketahun. Kompetisi bisnis yang semakin ketat menyebabkan setiap perusahaan publik untuk selalu mengevaluasi kinerjanya serta melakukan serangkaian perbaikan agar perusahaannya tetap tumbuh dan berkembang sehingga, dapat memenuhi permintaan konsumsi masyarakat, mencapai tujuan ekspansi, menjaga kelangsungan hidup perusahaan, serta meningkatkan kinerja keuangan perusahaannya. 
Persaingan antar perusahaan menuntut masing-masing perusahaan untuk memiliki performa yang baik. Penilaian performa perusahaan dapat dilihat dari kinerja keuanganya. Menurut Rudianto (2013:189) kinerja keuangan adalah hasil atau prestasi yang telah dicapai oleh manajemen dalam mengelola aset perusahaan selama periode tertentu. Kinerja keuangan digunakan sebagai tolak ukur untuk mengetahui dan mengevaluasi tingkat keberhasilan perusahaan berdasarkan aktivitas keuangan yang dilaksanakan. Menurut (Azzahra \& Nasib, 2019) menyatakan Informasi mengenai kinerja keuangan sangat penting bagi investor sebagai alat pengambilan keputusan berinvestasi. Kinerja keuangan dapat dilihat dengan menganalisis laporan keuangan dimana informasi keuangan memberikan gambaran atau peramalan dan berguna dalam pengambilan keputusan bagi investor ataupun calon investor untuk menentukan prospek perusahaan yang menguntungkan (Dewi et al., 2016).

Kinerja keuangan dapat dinilai dari rasio-rasio keuangan, dimana rasio profitabilitas paling sering dilihat karena rasio profitabilitas dapat menunjukkan bagaimana keberhasilan perusahaan dalam menghasilkan laba. Pengukuran penilaian kinerja keuangan dapat diukur menggunakan return on assets, yang mengukur keefektifan manajemen dalam menghasilkan laba dengan aset yang dimilikinya, (Azis, 2017). Penelitian mengenai kinerja keuangan ini sangat menarik untuk diteliti, mengingat 5 tahun terakhir ini kinerja keuangan sektor property dan real estate mengalami penurunan. Seperti yang dirangkum dalam Cnbcindonesia.com tanggal 19 september 2019, pemerintah mengatakan bahwa kinerja sektor property dan real estate mengalami penurunan atau melemah padahal sektor ini merupakan salah satu jangkar perekonomian yang merupakan salah satu sektor yang mampu menyerap tenaga kerja dalam jumlah besar dan memiliki efek berantai (multipler effect) serta backward linkage yang cukup besar kepada sektor ekonomi lainnya, yang sudah selayaknya memperoleh perhatian yang serius.

Kinerja keuangan (ROA) dari beberapa emiten property dan real estate yang terdaftar di BEI tahun 2014 sampai 2018 mengalami penurunan dan adapun yang berfluktuasi. Contohnya pada perusahaan CTRA, pada tahun 2014 kinerja keuangan CTRA mengalami penurunan sampai dengan tahun 2018 dimana pada tahun 2014 kinerja keuangan CTRA 7,71\% menurun hingga 1, 96\% pada tahun 2018, BSDE pada tahun 2014 kinerja keuangan 14,20\% menjadi 1,67\% pada tahun 2018 dan SMRA kinerja keuangan 9,02\% pada tahun 2014 menurun setiap tahunnya menjadi $1,71 \%$ tahun 2018. hal ini membuktikan masih lemahnya dan memburuknya kinerja keuangan pada perusahaan property dan real estate di Indonesia.

Kinerja keuangan dapat dipengaruhi oleh kepemilikan asing. Kepemilikan asing dilihat dari jumlah saham yang dimiliki asing dibagi dengan jumlah saham beredar. kepemilikan saham asing dapat meningkatkan kinerja keuangan, alasannya kemampuan yang dimiliki untuk memantau perusahaan lebih serius, memberikan insentif bagi para manajer dalam mengelola perusahaan dan investor asing akan mentransfer teknologi baru yang ada diperusahaan asing sehingga menghasilkan penghematan biaya operasional (Balagobei \& Velnampy, 2017).

Kinerja keuangan yang baik dapat dilihat dari kemampuan perusahaan dalam mengelola serta memanfaatkan assets yang dimilikinya untuk memperoleh laba serta kinerja keuangan yang baik juga dapat dilihat dari sejauh mana perusahaan dibiayai oleh utang dalam kegiatan operasinya atau disebut dengan leverage. Leverage dapat mempengaruhi kinerja keuangan perusahaan. Rasio leverage menurut (Kasmir, 2010:72) mengemukakan bahwa rasio leverage digunakan untuk melihat seberapa jauh perusahaan dibiayai oleh hutang atau pihak luar dengan kemampuan perusahaan yang dapat dilihat melalui aset. Rasio ini membandingkan jumlah beban hutang yang ditanggung oleh perusahaan dengan aset yang dimilikinya. Apabila ketergantungan perusahaan akan kreditur tinggi maka beban yang ditanggung perusahaan akan meningkat seperti 
biaya yang ditimbulkan dari utang, biaya bunga kepada kreditur maka profitabilitas perusahaan akan menurun karena laba digunakan untuk membayar utang sehingga kinerja keuangan akan menurun (Ifada \& Inayah, 2017).

Faktor lainnya yang dapat mempengaruhi kinerja keuangan adalah cash holding. Menurut (Garcia \& Teruel et al., 2009) cash holding merupakan rasio keuangan yang membandingkan jumlah kas atau setara kas yang dimiliki perusahaan dengan jumlah aktiva perusahaan diluar kas. Peningkatan kinerja keuangan akan terjadi apabila Jumlah uang kas/setara kas yang dimiliki berlebih sehingga memungkinkan perusahaan untuk menghindari tingginya pembiayaan dari eksternal serta memberikan fleksibelitas kepada perusahaan untuk memanfaatkan peluang investasi yang menguntungkan (Vijayakumaran \& Atchyuthan, 2017).

Sebaliknya, melalui pengurangan cash holding akan mengurangi free cash flow, potensi konflik antara manajer dengan pemegang saham akan menurun karena manajer akan terdorong meningkatkan kinerjanya untuk lebih lebih efektif dan efisien khususnya dalam pengelolaan kas yang dimiliki perusahaan. Jumlah uang kas yang tidak berlebih akan mendorong manajer bekerja lebih efektif dan teliti dalam membiayai pengeluaran yang benar-benar dibutuhkan perusahaan dan juga lebih efisien dengan tidak mengeluarkan kas secara berlebihan sehingga kebutuhan perusahaan dapat terpenuhi. Peningkatan efektivitas dan efisiensi manajer akan berdampak positif pada kinerja perusahaan secara keseluruhan terutama kinerja keuangan (Gill dan shah, 2012 dalam Damarjati et al., 2018).

Debt maturity juga menjadi salah satu faktor yang mempengaruhi kinerja keuangan. Debt maturity atau jatuh tempo utang. Berdasarkan survei oleh (Graham \& Harvey, 2001) penyelarasan waktu antara debt maturity dan aset dianggap sebagai faktor terpenting dalam memilih menerbitkan utang jangka panjang atau utang jangka pendek. Berdasarkan pandangan teori agensi maturitas utang yang pendek dapat mengurangi konflik keagenan. Penggunaan utang jangka pendek mengharuskan manajer untuk secara berkala memberikan informasi bagi investor dalam rangka mengevaluasi return dan risiko dengan demikian investor akan menilai ulang utang saat jatuh tempo berdasarkan informasi baru.pendekatan ini memitigasi masalah asset substitution dan masalah underinvestment (Jun \& Jen, 2003). Memperpendek debt maturity atau maturitas utang akan menurunkan underinvestment problem, sehingga perusahaan tetap mampu memanfaatkan seluruh peluang investasi yang dimilikinya tanpa terbatasi oleh kewajiban untuk memenuhi hak kreditur. Kewajiban kepada kreditur akan mengurangi return investasi karena resiko likuiditas yang ditimbulkan oleh debt maturity, memperpendek debt maturity akan diikuti oleh peningkatan kinerja keuangan (Damarjati dkk., 2018; Warmana \& Widnyana, 2017).

Pada penelitian terdahulu masih terdapat perbedaan atau ketidak konsistenan hasil penelitian seperti penelitian yang dilakukan Ifada \& Inayah, (2017) menunjukkan hasil leverage berpengaruh negatif signifikan terhadap kinerja keuangan. Penelitian yang dilakukan (Nopitasari dkk, (2018) bahwa leverage berpengaruh positif tetapi tidak signifikan pengaruhnya terhadap kinerja keuangan dan (Kusuma, 2018) leverage tidak berpengaruh terhadap kinerja keuangan. Penelitian terdahulu tentang pengaruh cash holding, debt maturity terhadap kinerja keuangan yang dilakukan di Indonesia masih jarang diteliti. Perbedaan penelitian ini dengan penelitian sebelumnya terletak pada objek yang diteliti, waktu penelitian dan pengukuran. Penelitian terdahulu banyak menggunakan return on assets (ROA) dan return on equity (ROE) sebagai pengukuran kinerja keuangan sedangkan penelitian ini menggunakan pengukuran cash flow return on asset (CFROA).

Tujuan penelitian ini untuk menganalisis pengaruh kepemilikan asing, leverage, cash holding dan debt maturity terhadap kinerja keuangan. Hasil penelitian ini diharapkan berguna 
bagi pihak-pihak berkepentingan dalam pengambilan keputusan yang akan meningkatkan kinerja keuangan perusahaan. untuk perusahaan diharapkan penelitian ini dapat menentukan rencana perusahaan kedepan untuk dapat bersaing serta meningkatkan kinerja keuangannya dan memiliki implikasi bagi pemangku kepentingan dalam perusahaan terutama bagi investor. Informasi dari kinerja keuangan dapat dijadikan pertimbangan investor dalam pengambilan keputusan yang menyangkut investasi.

\section{REVIU LITERATUR DAN HIPOTESIS Teori Keagenan (Agency Theory)}

Agency theory ( teori keagenan) adalah teori yang pada umumnya digunakan dalam kontrak bisnis. Anthony (2009:269) menyatakan bahwa di dalam teori keagenan terdapat istilah prinsipal dan agen, dimana prinsipal adalah pemegang saham atau investor, sedangkan agen adalah manajer atau CEO. Teori keagenan ada ketika salah satu pihak (prinsipal) menyewa pihak lain (agen) untuk melaksanakan jasa, prinsipal memberikan wewenang kepada agen untuk membuat keputusan dan mengelola perusahaan.

\section{Signalling Teory}

Teori signalling ini mengemukakan perusahaan yang baik akan dengan sengaja memberikan sinyal kepada pasar, sehingga pasar akan dapat membedakan perusahaan yang berkualitas baik dengan perusahaan yang berkualitas buruk. Teori ini termasuk kedalam teori akuntansi pragmatik yang dilihat dari perubahan perilaku terhadap informasi yang diterima oleh pemakai informasi. Perusahaan memberikan petunjuk bagi investor tentang bagaimana manajemen memandang prospek perusahaan atas suatu tindakan yang diambil. Salah satunya ketika emiten mengumumkan informasi, yang nanti akan berpengaruh terhadap naik turunnya harga sekuritas perusahaan yang melakukan pengumuman (Suwardjono, 2012:32).

\section{Kinerja Keuangan}

Kinerja keuangan adalah suatu analisis keuangan yang dilakukan untuk melihat sejauh mana perusahaan telah melaksanakan dengan menggunakan aturan-aturan pelaksanaan keuangan secara baik dan benar. Kinerja perusahaan sering dikaitkan dengan kondisi keuangan, kinerja merupakan yan paling utama yang harus dicapai perusahaan karena kinerja merupakan gambaran dari pencapaian perusahaan dalam periode tertentu (Fahmi, 2012).

\section{Kepemilikan Asing} Undang-Undang Republik Indonesia Nomor 25 Tahun 2007 Tentang Penanaman Modal, pasal 1 ayat 6 menyatakan kepemilikan asing merupakan perseorangan warga negara asing, badan usaha asing dan/atau pemerintah asing yang melakukan penanaman modal diwilayah negara Republik Indonesia. Kepemilikan asing merupakan proporsi dari jumlah saham yang dimiliki investor asing dari jumlah saham yang beredar (Ulfiyati et al., 2017).

\section{Leverage}

Rasio leverage menurut (Kasmir, 2010:72) mengemukakan bahwa rasio leverage digunakan untuk melihat seberapa jauh perusahaan dibiayai oleh hutang atau pihak luar dengan kemampuan perusahaan yang dapat dilihat melalui aset. Rasio ini membandingkan jumlah beban hutang yang ditanggung oleh perusahaan dengan aset yang dimilikinya. 


\section{Cash Holding}

Kas (cash) merupakan asset yang paling liquid diantara banyak aset serta mudah dipindah tangankan dalam transaksi. Menurut Athur, (270:2010) kas terdiri dari beberapa macam, yang termasuk golongan kas yaitu kas yang ada ditangan (cash on hand), seperti uang koin \& uang kertas, cash register dan petty cash. Stice (2007) menyatakan kas tergolong kedalam aset lancar yang terdiri dari uang logam, uang kertas, dan unsur-unsur lain yang berfungsi (1) sebagai alat pertukaran dan (2) memberikan dasar untuk perhitungan akuntansi.

\section{Debt Maturity}

Dalam penggunaan utang dari pendanaan eksternal perusahaan perlu memperhatikan debt maturity atau jatuh tempo utang. Pemilihan debt maturity akan mempengaruhi nilai perusahaan yang akan berimbas kepada kinerja keuangan perusahaan. Menurut (Smart, 2004 dalam Abadi, 2013) mengemukan apabila debt maturity atau jatuh tempo utang perusahaan jangka panjang maka perusahaan akan membayar bunga yang tinggi dari utang tersebut karena cost of debt akan meningkat sehingga akan mempengaruhi cost of capital yang akan mempengaruhi nilai perusahaan. Pernurunan nilai perusahaan akan berdampak pada penurunan kinerja keuangan.

\section{Pengaruh Kepemilikan Asing Terhadap Kinerja Keuangan}

Berdasarkan prespektif teori keagenan pemisahan kepemilikan dan pengendalian suatu perusahaan dapat menyebabkan asimetri informasi dan konflik keagenan (antara principal dan agent) sehingga dapat memicu agency cost (biaya keagenan). Penyebab dari adanya biaya keagenan salah satunya adalah adanya kepemilikan saham yang dimiliki oleh pihak asing atau foreign ownership. Hal ini terjadi karena keberadaan kepemilikan asing dalam suatu perusahaan dapat meminimalkan terjadinya agency problem antara manajer dan pemegang saham. Pemegang saham menyewa manajer atau CEO dan berharap manajer tersebut dapat bertindak sesuai dengan kepentingan mereka sehingga agen harus sama produktifnya seperti pemilik. Sesuai dengan teori keagenan untuk meningkatkan keuntungan yang diperoleh perusahaan, kepemilikan asing atau investor asing akan membawa keuangan, pemasaran dan teknologi yang dapat membantu manajer dalam meningkatkan kinerja keuangan perusahaan (Yavas, C. V., \& Erdogan, 2017).

Menurut penelitian Balagobei \& Velnampy (2017) kepemilikan asing memiliki pengaruh yang positif terhadap kinerja keuangan, artinya bahwa semakin tinggi tingkat kepemilikan asing semakin meningkat kinerja keuangan perusahaan. Berdasarkan penjelasan di atas dapat ditarik hipotesis seperti dibawah ini:

$\mathbf{H}_{1}$ : Kepemilikan asing berpengaruh positif terhadap kinerja keuangan

\section{Pengaruh Leverage Terhadap Kinerja Keuangan}

Menurut pandangan signalling teory menekankan pentingnya informasi yang dikeluarkan perusahaan terhadap keputusan investasi pihak diluar perusahaan. Informasi ini merupakan unsur penting bagi investor dan pelaku bisnis karena informasi pada hakekatnya menyajikan dan menggambarkan keadaan masa lalu, masa kini dan masa yang akan datang bagi kelangsungan hidup suatu perusahaan dan bagaimana pasaran efeknya. Pada waktu informasi diumumkan dan semua pelaku pasar sudah menerima informasi, pelaku pasar akan terebih dahulu menginterprestasikan dan menganalisis informasi tersebut sebagai sinyal baik (good news) atau sinyal buruk (bad news). Beberapa investor lebih cenderung menghindari atau tidak menyukai perusahaan yang memiliki resiko yang tinggi. Brigham dan Houston (2011:103), para investor 
tertentu menginginkan prospek pengembalian yang tinggi, namun mereka enggan untuk menghadapi resiko, karena investor ini lebih tertarik pada saham yang tidak menanggung terlalu banyak resiko dari resiko hutang yang tinggi.

Sesuai dengan signalling teori, merujuk pada penelitian (Enekwe et al., 2014) menganalisis tentang pengaruh leverage yang diproksikan dengan debt ratio terhadap kinerja keuangan pada perusahaan farmasia di Nigeria, hasil menyatakan leverage berpengaruh negatif terhadap kinerja keuangan. Bila debt ratio meningkat maka kinerja keuangan akan menurun. Perusahaan yang mempunyai leverage atau utang yang tinggi maka akan mengurangi laba bersih (net income) karena akibat dari membayar beban keuangan dari utang yang akan berdampak pada penurunan return on asset sebagai ukuran dari kinerja keuangan. Hasil penelitian yang sama yang dilakukan oleh (Triwacananingrum \& Hidayat, 2014) serta (Sulastri, 2016) menemukan bahwa leverage mempunyai pengaruh negatif terhadap kinerja keuangan. Berdasarkan penjelasan diatas hipotesis penelitian ini adalah sebagai berikut:

$\mathbf{H}_{2}$ : Leverage berpengaruh negatif terhadap kinerja keuangan

\section{Pengaruh Cash Holding Terhadap Kinerja Keuangan}

Berdasarkan teori keagenan terdapat hipotesis yang terkait dengan cash holding yaitu risk reduction hypothesis. Dalam Agency theory terdapat Risk-Reduction Hypothesis menganggap cash holdings sebagai investasi bebas risiko bagi perusahaan. Manajer akan meningkatkan cash holdings untuk menghindari dan mengurangi eksposur risiko perusahaan sehingga memberikan risiko yang positif pada proyek-proyek net present value (NPV) (Tong, 2006). Penerapan teori keagenan pada penelitian ini berkaitan dengan prinsipal yang menginginkan manajer mengelola dan mengembangkan perusahaan dengan baik, salah satunya dalam pengelolaan kas yang merupakan bagian paling likuid dalam aset.

Merujuk pada penelitian (Martinez-Sola et al., 2013) berpendapat bahwa selama adanya kompetisi perusahaan pada pasar keuangan perusahaan selalu memegang kas untuk peningkatan tingkat kinerja perusahaan yang optimal. Penelitian Vijayakumaran \& Atchyuthan (2017) dan Palazzo (2011) menemukan hasil bahwa cash holding berpengaruh positif terhadap kinerja keuangan perusahaan. Perusahaan cendrung menyimpan uang tunai atau memegang uang tunai sebagai motif pencegahan (Palazzo, 2011). Semakin tinggi cash hoding atau jumlah kas semakin meningkat kinerja keuangan perusahaan. Berdasarkan penjelasan diatas maka hipotesis pada penelitian ini adalah sebagai berikut:

$\mathbf{H}_{3}$ : Cash holding berpengaruh positif terhadap kinerja keuangan

\section{Pengaruh Debt Maturity Terhadap Kinerja Keuangan}

Myers, 1977 merekomendasikan agar memperpendek debt maturity atau jatuh tempo hutang guna mengatasi underinvestment problem yang akan berimbas pada kinerja keuangan perusahaan. Saat manajer memiliki informasi privat yang menguntungkan, mereka diharapkan dapat menghindari penguncian utang jangka panjang. Penguncian terjadi karena saat perusahaan mengajukan utang jangka panjang, perusahaan akan terkunci oleh kontrak dari utang jangka panjang tersebut. Adanya penghindaran terhadap penguncian utang jangka panjang menyebabkan perusahaan lebih memilih utang jangka pendek. Pemilihan utang jangka pendek juga terkait dengan agency cost yang lebih rendah. Perusahaan dengan agency cost yang tinggi dianggap dianggap sebagai pertanda buruk karena manajer menggunakan dana berlebih dan selanjutnya akan berdampak pada penurunan profitabilitas yang dapat menurunkan kinerja keuangan perusahaan. 
Penelitian (Damarjati et al., 2018) menemukan hasil debt maturity dengan proksi utang jangka pendek memiliki pengaruh positif dan signifikan terhadap kinerja keuangan. Hal ini dapat disimpulkan semakin tinggi jumlah utang jangka pendek pada perusahaan akan menurunkan underinvestment problem, karena perusahaan tetap mampu memanfaatkan seluruh peluang investasi yang dimiliki tanpa dibatasi oleh kewajiban memenuhi hak kreditor yang akan mengurangi return investasi. Berdasarkan penjelasan di atas maka dapat dirumuskan hipotesisnya sebagai berikut:

$\mathbf{H}_{4}$ : Debt maturity berpengaruh positif terhadap kinerja keuangan

\section{Kerangka Konseptual}

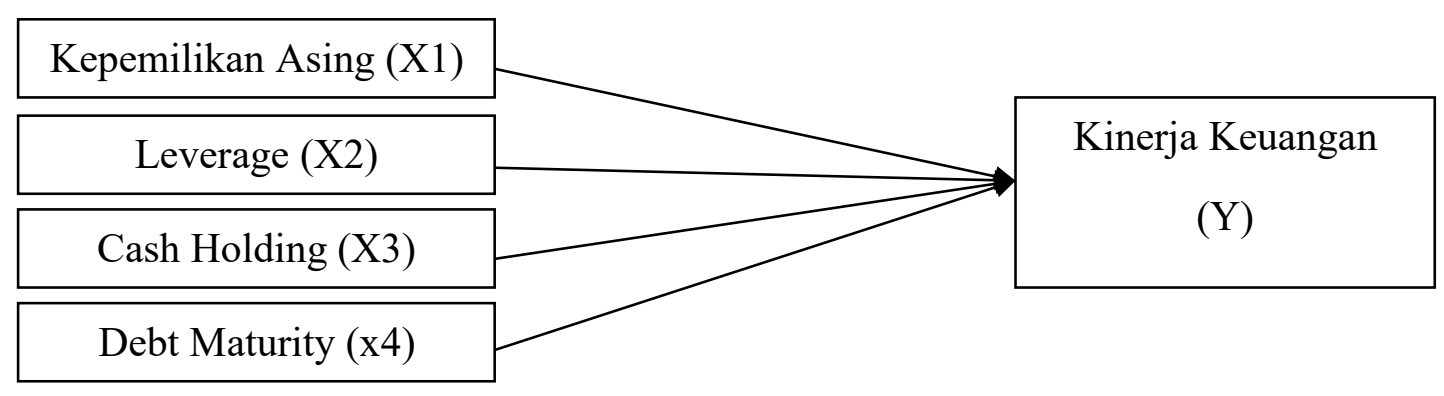

\section{Gambar 1. Kerangka Konseptual}

\section{METODE PENELITIAN}

\section{Sampel dan Jenis Penelitian}

Jenis penelitian ini yaitu kuantitatif kausalitas. Penelitian kuantitif kausalitas adalah penelitian yang bertujuan untuk menganalisis hubungan antara satu variabel dengan variabel lainnya atau bagaimana suatu variabel mempengaruhi variabel lain. Populasi dalam penelitian ini adalah seluruh perusahaan property dan real estate yang terdaftar di Bursa Efek Indonesia (BEI) pada periode pengamatan tahun 2014-2018. Sampel penelitian ini berjumlah berjumlah 24 perusahaan. Metode pengambilan sampel pada penelitian ini menggunakan metode purposive sampling yaitu pengambilan sampel sesuai dengan kriteria tertentu, dengan rincian sebagai berikut:

Tabel 1. Kriteria Pemilihan Sampel

\begin{tabular}{cll}
\hline No & \multicolumn{1}{c}{ Kriteria } & Jumlah \\
\hline 1 & $\begin{array}{l}\text { Perusahaan property dan real estate yang terdaftar di Bursa } \\
\text { Efek Indonesia (BEI) selama tahun penelitian yaitu 2014-2018. }\end{array}$ & 55 \\
2 & $\begin{array}{l}\text { Perusahaan property dan real estate yang tidak menerbitkan } \\
\text { laporan keuangan yang lengkap selama periode penelitian }\end{array}$ & \\
& $\begin{array}{l}\text { 2014-2018. } \\
3\end{array}$ & $\begin{array}{l}\text { Perusahaan property dan real estate yang tidak menyajikan } \\
\text { laporan keuangan dengan mata uang rupiah }\end{array}$ \\
4 & $\begin{array}{l}\text { Perusahaan property dan real estate yang tidak menyajikan } \\
\text { informasi yang terkait dengan variabel penelitian }\end{array}$ & \\
& Jumlah perusahaan yang menjadi sampel penelitian & (13) \\
\hline
\end{tabular}

Sumber: Data Olahan Peneliti (2020) 


\section{Jenis, Sumber dan Teknik Pengumpulan Data}

Jenis data yang digunakan dalam penelitian ini adalah data dokumenter dan data sekunder. Sedangkan, teknik pengumpulan data yang digunakan dalam penelitian ini adalah studi pustaka dan studi dokumentasi.

\section{Variabel Penelitian dan Pengukuran}

\section{Kinerja Keuangan}

Kinerja keuangan merupakan prestasi yang telah dicapai suatu perusahaan dalam suatu periode tertentu yang menggambarkan tingkat kesehatan perusahaan (Sutrisno, 2009:53). Penelitian ini menggunakan pengukuran dalam penelitian (Siregar et al., 2017). Kinerja keuangan diukur dengan Cash Flow Return on Asset (CFROA) yaitu laba sebelum pajak ditambah depresiasi dibagi dengan total asset. CFROA dihitung dengan rumus sebagai berikut:

$$
\text { CFROA }=\frac{\text { EBIT }+ \text { DEP }}{\text { Total Assets }}
$$

\section{Kepemilikan Asing}

Kepemilikan asing adalah gambaran seberapa besar atau kecilnya pemilik saham oleh badan usaha asing dan perorangan asing. Kepemilikan asing diukur dari jumlah saham yang dimiliki oleh pihak asing dibagi dengan total jumlah saham yang beredar (Balagobei \& Velnampy, 2017). Kepemilikan asing dihitung dengan rumus:

$$
\text { Kepemilikan Asing }=\frac{\text { Jumlah saham pihak asing }}{\text { Total jumlah saham beredar }}
$$

\section{Leverage}

Leverage merupakan rasio yang digunakan untuk mengukur seberapa besar perusahaan dibiayai oleh utang atau untuk mengukur kemampuan perusahaan dalam memenuhi kewajibannya (Fahmi, 2014:72). Rasio leverage diproksikan dengan debt to equity ratio (DER) yaitu jumlah kewajiban dibagi dengan total equity. DER dihitung dengan rumus sebagai berikut:

\section{Cash Holding}

$$
\text { DER }=\frac{\text { Total debt }}{\text { total equity }}
$$

Cash holding Menurut (Opler et al., 1999) adalah rasio kas atau juga dikenal sebagai jumlah kas terhadap aset bersih yang diformulasikan untuk menunjukkan jumlah kas yang tersedia dari total aset perusahaan karena mereka percaya bahwa fungsi utama dari segala jenis aset adalah untuk menghasilkan laba bagi perusahaan. Cash holding pada penelitian ini diukur dengan menggunakan rasio kas. Rasio kas dikenal sebagai rasio untuk mengukur jumlah kas dan setara kas dibagi dengan aset bersih. Rumus yang digunakan adalah sebagai berikut:

$$
\mathrm{CR}=\frac{\text { Cash }}{\text { Net Assets }}
$$

\section{Debt Maturity}

Debt maturity merupakan jatuh tempo hutang. Penyelarasan waktu utang antara debt maturity dianggap sebagai salah satu faktor terpenting dalam memilih waktu utang, apakah perusahaan cendrung memilih utang jangka pendek atau utang jangka panjang. Pengukuran debt maturity 
Merujuk pada penelitian (Damarjati, 2018) yaitu perbandingan utang jangka pendek dengan total utang. Pengukuran debt maturity dirumuskan sebagai berikut:

$$
\text { Debt maturity }=\frac{\text { Utang jangka pendek }}{\text { Total utang }}
$$

\section{Metode Analisis Data}

Analisis data pada penelitian ini diuji menggunakan program e-views. Dengan menggunakan analisis deskriptif dan analisis induktif, model regresi yang digunakan yaitu :

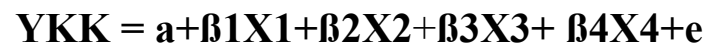

\section{HASIL DAN PEMBAHASAN Analisis Deskrptif}

Tabel 2

Hasil statistik deskriptif

\begin{tabular}{cccccc}
\hline Variabel & Mean & Median & Maximum & Minimum & Std. Dev. \\
\hline KK & 0.064189 & 0.048355 & 0.532270 & -0.032460 & 0.074188 \\
KA & 0.154034 & 0.113865 & 0.777360 & 0.000540 & 0.160556 \\
LEV & 0.739804 & 0.656795 & 1.798830 & 0.035690 & 0.432727 \\
CH & 0.132763 & 0.117300 & 0.512400 & -0.237860 & 0.107176 \\
DM & 0.511893 & 0.473015 & 0.992570 & 0.167620 & 0.217520 \\
& & $\mathbf{N}=\mathbf{1 2 0}$ & &
\end{tabular}

Sumber: Data diolah peneliti menggunakan Eviews 10 tahun 2020

Berdasarkan Tabel 2 di atas menunjukkan bahwa variabel KK (Kinerja Keuangan) sebagai variabel dependen dalam penelitian ini memiliki nilai rata-rata 0,064189 dengan standar deviasi sebesar 0,074188. Nilai KK maksimum sebesar 0,532270 dan nilai minimum KK sebesar 0,032460. Variabel KA (Kepemilikan Asing) yang merupakan variabel independen dengan tanda X1 memiliki rata-rata sebesar 0.154034 dengan standar deviasi sebesar 0.160556. Nilai maksimum KA sebesar 0.777360 dan nilai minimum KA sebesar 0.000540. Variabel LEV (Leverage) yang merupakan variabel independen dengan tanda X2 memiliki rata-rata sebesar 0.739804 dengan standar deviasi sebesar 0.432727. Nilai maksimum LEV sebesar 1.798830 dan nilai minimum LEV sebesar 0.035690 .

\section{Analisis Induktif}

Analisis Model Regresi

Berdasarkan hasil uji Chow Test dan uji Hausmant Test yang terpilih untuk digunakan dalam penelitian ini adalah Fixed Effect Model, dan harus dilakukan uji asumsi klasik. 
Tabel 3

Hasil Chow Test atau Likelyhood Test

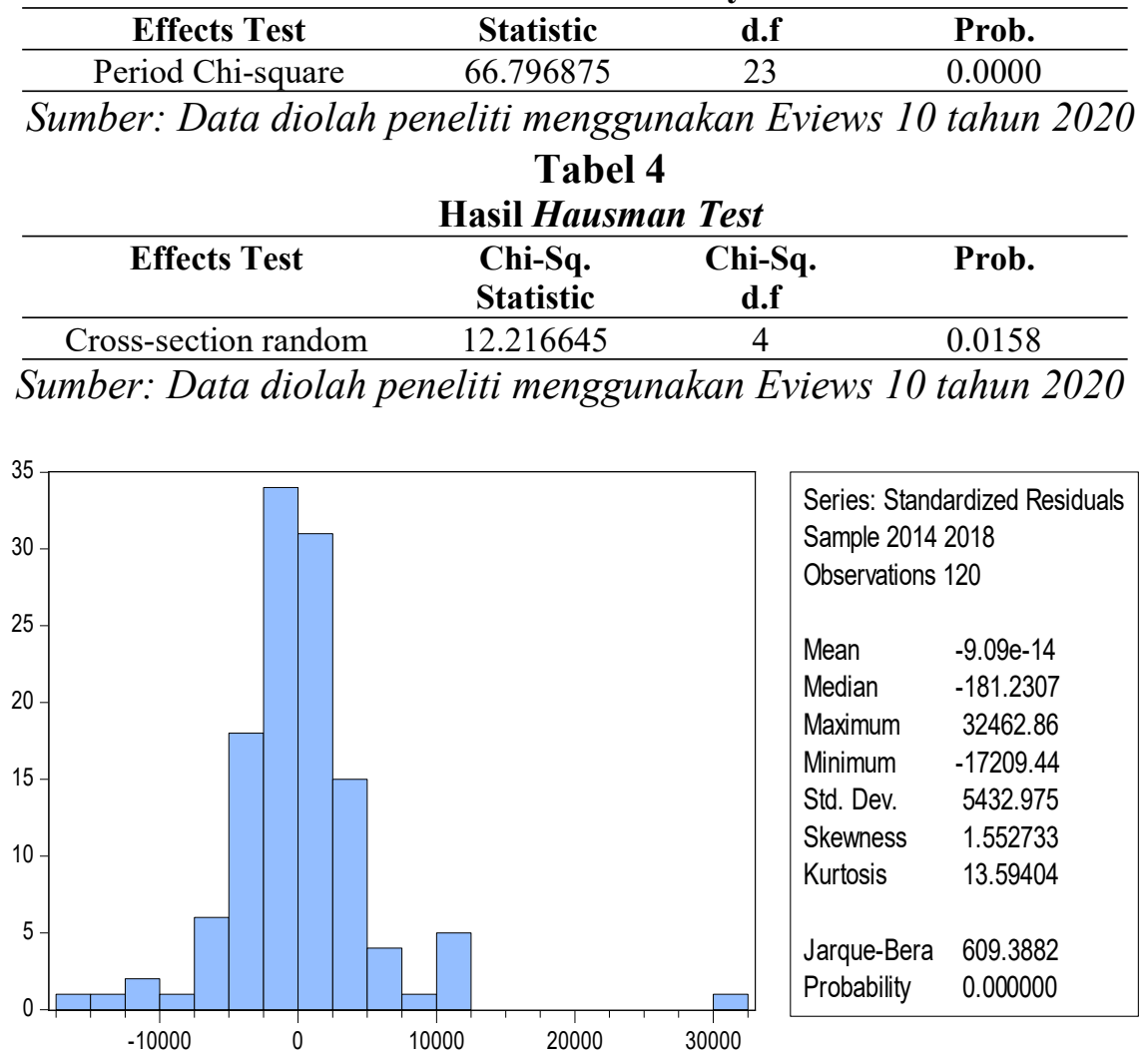

Sumber: Data olahan Eviews 10 tahun 2020

Gambar 2. Hasil Uji Normalitas Residual

Tabel 5

Hasil Uji Heterokoedastisitas

\begin{tabular}{cc}
\hline Variabel & Probabilitas \\
\hline KA & 0,0861 \\
LEV & 0,2509 \\
CH & 0,9004 \\
DM & 0,7219 \\
\hline
\end{tabular}

Sumber: Data diolah peneliti menggunakan Eviews 10 tahun 2020

Tabel 6

Hasil Uji Multikolinearitas

\begin{tabular}{ccccc}
\hline & KA & LEV & CH & DM \\
\hline KA & 1.000000 & -0.138517 & -0.186695 & 0.185002 \\
LEV & -0.138517 & 1.000000 & 0.232263 & -0.279506 \\
CH & -0.186695 & 0.232263 & 1.000000 & -0.182853 \\
DM & -0.185002 & -0.279506 & -0.182853 & 1.000000 \\
\hline
\end{tabular}

Sumber: Data diolah peneliti menggunakan Eviews 10 tahun 2020 


\section{Tabel 7}

Hasil Uji Autokorelasi

\begin{tabular}{c|c}
\hline \multicolumn{2}{c}{ Uji Durbin Watson } \\
\hline Model & Durbin-Watson Stat \\
Penelitian & 2.123492 \\
\hline
\end{tabular}

Sumber: Data olahan Eviews 10 tahun 2020

\section{Model Regresi Panel}

Berdasarkan hasil estimasi model regresi pada Chow Test dan Hausman Test dan yang telah dilakukan, maka digunakan pendekatan Fixed effect model untuk mengestimasi pengaruh kepemilikan asing, leverage, cash holding dan debt maturity terhadap kinerja keuangan. Adapun hasil regresi panel dengan menggunakan pendekatan Fixed effect model untuk regresi yang digunakan dalam penelitian ini yaitu:

\section{Tabel 8}

Hasil Regresi Panel

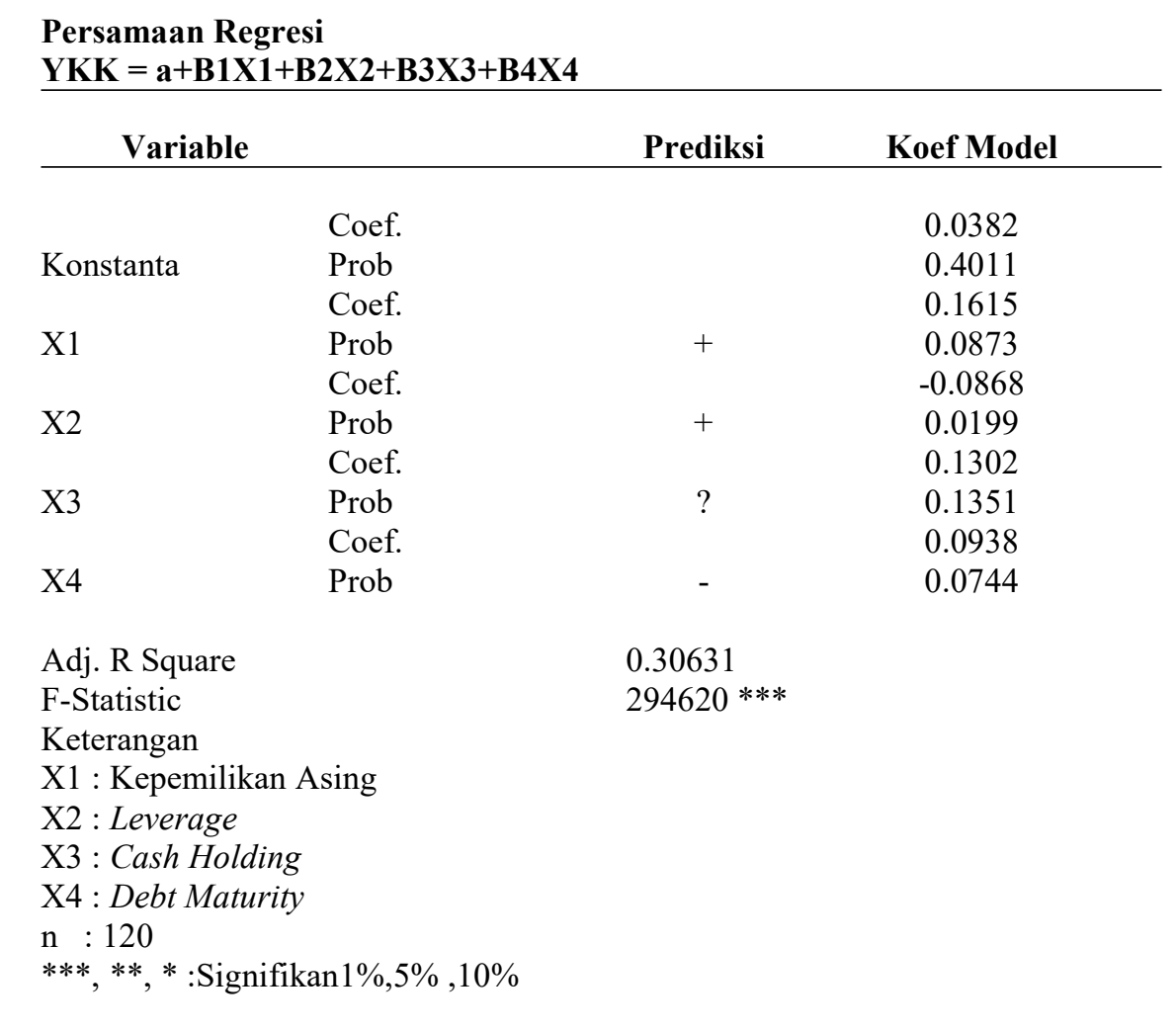

Sumber : Data diolah peneliti menggunakan Eviews 10 tahun 2020

Berdasarkan hasil regresi pada tabel 8 menunjukkan bahwasanya nilai adjusted R-square diperoleh sebesar 30,6\%. Hal ini menjelaskan bahwa kontribusi variabel independen terhadap variabel dependen pada persamaan regresi sebesar 30,6\% sedangkan sebesar 69,4\% dijelaskan oleh faktor lain yang tidak terdapat pada variabel penelitian ini. Pada tabel 11 diperoleh hasil bahwasanya variabel independen pertama memiliki hasil koefisien $\beta_{1} X_{1}$ bernilai positif yaitu 
sebesar 0,1615 dengan tingkat probabilitas sebesar $>\alpha 5 \%$ yaitu sebesar $0,0873>5 \%$ sehingga dapat disimpulkan bahwa hipotesis pertama ditolak. Dimana hipotesis pertama berbunyi "kepemilikan asing berpengaruh positif terhadap kinerja keuangan".

Selanjutnya pengujian variabel independen kedua memiliki hasil koefisien $\beta_{2} X_{2}$ bernilai negatif yaitu sebesar - 0.0868 dengan tingkat probabilitas sebesar $<\alpha 5 \%$ yaitu sebesar $0,0199<$ $5 \%$ sehingga dapat disimpulkan bahwa hipotesis kedua diterima. Dimana hipotesis kedua berbunyi "leverage berpengaruh negatif terhadap kinerja keuangan".

Variabel independen ketiga memiliki hasil koefisien $\beta_{3} X_{3}$ bernilai positif yaitu sebesar 0.1302 dengan tingkat probabilitas sebesar $>\alpha 5 \%$ yaitu sebesar $0.1351>5 \%$ sehingga dapat disimpulkan bahwa hipotesis ketiga ditolak. Dimana hipotesis ketiga berbunyi "cash holding berpengaruh positif terhadap kinerja keuangan".

Pengujian variabel keempat memiliki hasil koefisien $\beta_{4} \mathrm{X}_{4}$ bernilai positif yaitu sebesar 0.0938 dengan tingkat probabilitas sebesar $>\alpha 5 \%$ yaitu sebesar $0.0744>5 \%$ sehingga dapat disimpulkan bahwa hipotesis ketiga ditolak. Dimana hipotesis ketiga berbunyi "debt maturity berpengaruh positif terhadap kinerja keuangan".

\section{Uji Model}

Berdasarkan hasil regresi pada tabel 8 menunjukkan bahwasanya nilai adjusted R-square diperoleh sebesar 30,6\%. Hal ini menjelaskan bahwa kontribusi variabel independen terhadap variabel dependen pada persamaan regresi sebesar 30,6\% sedangkan sebesar $69,4 \%$ dijelaskan oleh faktor lain yang tidak terdapat pada variabel penelitian ini.

Berdasarkan hasil regresi pada tabel 8 diketahui bahwa F-statistik signifikan pada 1\%, yaitu lebih kecil dari signifikan yang telah ditentukan pada penelitian ini yaitu 5\%. Hal ini menandakan bahwa model regresi panel diterima atau model regresi ini menunjukkan tingkatan yang baik (good overall model fit) sehingga model regresi dapat digunakan mengukur pengaruh kepemilikan asing, leverage, cash holding dan debt maturity terhadap kinerja keuangan.

Model persamaan regresi yang digunakan untuk menguji hipotesis pertama mengenai pengaruh kepemilikan asing terhadap kinerja keuangan yang disimbolkan dengan $\beta_{1} X_{1}$. Sesuai dengan hasil yang diperoleh pada tabel 8 diketahui bahwa koefisien $\beta_{1} \mathrm{X}_{1}$. bernilai positif yaitu 0,1615 dengan t-hitung 1,7280 dan tidak signifikan pada $\alpha 5 \%$. Hal ini berarti kepemilikan asing tidak berpengaruh terhadap kinerja keuangan sebab nilai signifikansi $>\alpha 5 \%$, yaitu $0,0873>5 \%$ serta, t-hitung $<\mathrm{t}$-tabel yaitu, 1,7280 $<2,080$. Sehingga dapat disimpulkan bahwa hipotesis pertama yang berbunyi " kepemilikan asing berpengaruh positif terhadap kinerja keuangan" ditolak.

Model regresi yang digunakan untuk menguji hipotesis kedua untuk menguji pengaruh leverage terhadap kinerja keuangan yang disimbolkan dengan $\beta_{2} \mathrm{X}_{2}$. Sesuai dengan hasil yang diperoleh pada tabel 8 diketahui bahwa koefisien $\beta_{2} X_{2}$. bernilai negatif yaitu $-0,0868$, dengan $t-$ hitung 2,3686 dan signifikan pada $\alpha 5 \%$. Hal ini berarti leverage memiliki pengaruh terhadap kinerja keuangan sebab nilai signifikansi $<\alpha 5 \%$, yaitu $0,0199<5 \%$ serta, t-hitung $>$ t-tabel yaitu, 2,3686 > 2,080 dan hal ini berarti bahwa hipotesis kedua diterima. Hipotesis kedua mengindikasikan bahwa leverage memiliki pengaruh signifikan negatif terhadap kinerja keuangan.

Hipotesis ketiga yang diuji dengan menggunakan model regresi untuk menguji pengaruh cash holding terhadap kinerja keuangan yang disimbolkan dengan $\beta_{3} X_{3}$. Sesuai dengan hasil yang diperoleh pada tabel 8 diketahui bahwa koefisien $\beta_{3} X_{3}$. bernilai positif yaitu 0,1302 dengan $t-$ hitung 1,5075 dan tidak signifikan pada $\alpha 5 \%$. Hal ini berarti cash holding tidak berpengaruh 
terhadap kinerja keuangan sebab nilai signifikansi $>\alpha 5 \%$, yaitu 0,1351 $>5 \%$ serta, t-hitung $<$ t-tabel yaitu, 1,5075 < 2,080. Sehingga dapat disimpulkan bahwa hipotesis ketiga yang berbunyi " cash holding berpengaruh positif terhadap kinerja keuangan" ditolak.

Hipotesis keempat yang diuji dengan menggunakan model regresi untuk menguji pengaruh debt maturity terhadap kinerja keuangan yang disimbolkan dengan $\beta_{4} \mathrm{X}_{4}$.. Sesuai dengan hasil yang diperoleh pada tabel 8 diketahui bahwa koefisien $\beta_{4} \mathrm{X}_{4}$. bernilai positif yaitu 0,0938 dengan t-hitung 1,8044 dan tidak signifikan pada $\alpha$ 5\%. Hal ini berarti debt maturity tidak berpengaruh terhadap kinerja keuangan sebab nilai signifikansi $>\alpha 5 \%$, yaitu $0,0744>5 \%$ serta, t-hitung $<$ t-tabel yaitu, 1,8044 $<2,080$. Sehingga dapat disimpulkan bahwa hipotesis keempat yang berbunyi “ debt maturity berpengaruh positif terhadap kinerja keuangan" ditolak.

\section{Pembahasan}

\section{Pengaruh Kepemilikan Asing terhadap Kinerja Keuangan}

Hipotesis pertama (H1) dalam penelitian ini adalah kepemilikan asing berpengaruh positif terhadap kinerja keuangan perusahaan. Berdasarkan hasil penelitian pada perusahaan property dan real estate yang terdaftar di BEI pada tahun 2014-2018, ditemukan bahwa hipotesis (H1) ditolak, hal ini menunjukkan bahwa kepemilikan asing tidak berpengaruh terhadap kinerja keuangan. Hal ini dapat dilihat dari hasil regresi panel pada tabel 8 dimana, diperoleh koefisien regresi kepemilikan asing 0,1615 dan juga menunjukkan nilai signifikan variabel $\beta_{1} \mathrm{X}_{1}$ lebih besar dari $\alpha 5 \%$, yaitu $0,0873>5 \%$ serta, t-hitung $<$ t-tabel yaitu, 1,7280<2,080. Sehingga dapat disimpulkan bahwa kepemilikan asing tidak berpengaruh terhadap kinerja keuangan.

Hasil penelitian ini konsisten dengan penelitian yang dilakukan oleh Nugrahawati (2019), Pangaribuan (2017), dan Admaja (2016). Menurut Nugrawati (2019) kepemilikan saham oleh pihak asing atau pihak luar negri tidak memiliki pengaruh terhadap kinerja keuangan karena kepemilikan asing bukanlah satu-satunya kepemilikan yang dapat menggerakkan harga saham secara signifikan. Besar kecilnya jumlah kepemilikan asing yang dimiliki perusahaan tidak akan mempengaruhi kinerja keuangan. Menurut Pangaribuan (2017) menemukan fakta yang didapat dillapangan bahwa kepemilikan asing hanya berkompromi dengan pihak manajemen yang membahas keuntungan dalam sisi pribadi tidak pada keuntungan secara umum. Sehingga kepemilikan asing tidak berpengaruh terhadap kinerja keuangan.

Hasil penelitian bertentangan dengan Hermiyetti (2016) yang menemukan bahwa kepemilikan asing berpengaruh positif terhadap kinerja keuangan perusahaan. pada penelitian tersebut dijelaskaan bahwa pemilik asing mampu menyuarakan kepentingan pemilik secara luas jika terdapat kebijakan manajemen yang dapat merugikan karena adanya benturan kepentingan antara manajemen dan pemilik. Kepemilikan asing secara aktif mengawasi perkembangan perusahaan melalui konfirmasi langsung kepada manajemen.

Faktor lain yang dianggap dapat menyebabkan hipotesis pertama ditolak karena jumlah kepemilikan asing pada perusahaan property dan real estate hanya sedikit seperti perusahaan Agung Podomoro Land Tbk yang hanya memiliki kepemilikan asing sebesar 1,2\%, City Retail Developments Tbk memiliki kepemilikan asing 4,7\%, Ristia Bintang Mahkota Sejati Tbk memiliki kepemilikan asing 0,1\% serta Pikko Land Development Tbk memiliki kepemilikan asing 5,6\%, dan tidak semua perusahaan property dan real estate yang terdaftar pada BEI mempunyai kepemilikan asing. Kedua, variabel kepemilikan asing pada perusahaan property dan real estate pada periode penelitian yaitu 2014-2018, menunjukkan angka yang rendah rata-rata berkisar 1\% - 25\%. Karena rendahnya kepemilikan asing pada perusahaan lokal, pemilik asing kurang memiliki power dalam pengambilan keputusan dan pengawasan, hal tersebut 
menyebabkan pemilik asing dianggap tidak bekerja efektif, tidak ikut dalam pengambilan keputusan perusahaan dan dianggap tidak memiliki manfaat dalam perkembangan perusahaan.

\section{Pengaruh Leverage terhadap Kinerja Keuangan}

Hipotesis kedua $(\mathrm{H} 2)$ dalam penelitian ini adalah leverage berpengaruh negatif terhadap kinerja keuangan perusahaan, semakin tinggi leverage suatu perusahaan maka kinerja keuangan akan menurun. Berdasarkan hasil penelitian pada perusahaan property dan real estate yang terdaftar di BEI pada tahun 2014-2018, ditemukan bahwa hipotesis (H2) diterima, hal ini menunjukkan bahwa leverage berpengaruh negatif terhadap kinerja keuangan. Hal ini dapat dilihat dari hasil regresi panel pada tabel 8 dimana, diperoleh koefisien regresi leverage $-0,0868$ dan juga menunjukkan nilai signifikan variabel $\beta_{2} X_{2}$ lebih kecil dari $\alpha 5 \%$, yaitu $0,0199<5 \%$ serta, $t$ hitung $>$ t-tabel yaitu, 2,3686 $>2,080$ dan hal ini berarti bahwa leverage berpengaruh negatif terhadap kinerja keuangan. Leverage memiliki pengaruh terhadap kinerja keuangan sebesar, $8,7 \%$.

Hasil penelitian ini konsisten dengan penelitian yang dilakukan oleh (Triwacananingrum \& Hidayat, 2014) serta (Sulastri, 2016). Menurut Sulastri (2016) menemukan bahwa leverage mempunyai pengaruh negatif terhadap kinerja keuangan karena tingginya leverage mengindikasikan bahwa utang perusahaan yang tinggi, sehingga perusahaan memiliki tingkat kebangkrutan yang tinggi sehingga dinilai buruk oleh investor dan berujung pada penurunan kinerja keuangan. Enekwe et al., (2014) leverage yang tinggi akan menurunkan kinerja keuangan . Apabila perusahaan mempunyai utang yang tinggi maka akan mengurangi jumlah laba bersih (net income) akibat dari membayar beban keuangan dari utang sehingga akan mengakibatkan penurunan profit yang berdampak pada penurunan kinerja keuangan.

Berdasarkan hasil penelitian, maka dapat disimpulkan bahwa semakin tinggi tingkat leverage pada perusahaan maka semakin menurun kinerja keuangan perusahaan. terbukti disaat perusahaan mempunyai utang yang tinggi maka laba yang dimiliki perusahaan akan berkurang karena laba digunakan untuk membayar utang ditambah dengan bunga pinjaman yang akan memperburuk kinerja keuangan perusahaan. perusahaan yang mempunyai leverage yang tinggi memiliki tingkat ketergantungan pendanaan yang tinggi kepada pihak eksternal, oleh karena itu leverage merupakan salah satu faktor yang berpengaruh terhadap kinerja keuangan.

\section{Pengaruh Cash Holding terhadap Kinerja Keuangan}

Hipotesis ketiga (H3) dalam penelitian ini adalah cash holding berpengaruh positif terhadap kinerja keuangan perusahaan. Berdasarkan hasil penelitian pada perusahaan property dan real estate yang terdaftar di BEI pada tahun 2014-2018, ditemukan bahwa hipotesis (H3) ditolak, hal ini menunjukkan bahwa cash holding tidak berpengaruh terhadap kinerja keuangan. Hal ini dapat dilihat dari hasil regresi panel pada tabel 8 dimana, diperoleh koefisien regresi cash holding bernilai positif yaitu 0,1302 tetapi nilai signifikan variabel $\beta_{3} \mathrm{X}_{3}$ lebih besar dari $\alpha 5 \%$, yaitu $0,1351>5 \%$ serta, t-hitung $<\mathrm{t}$-tabel yaitu, 1,5075 $<2,080$. Sehingga dapat disimpulkan bahwa cash holding tidak berpengaruh terhadap kinerja keuangan.

Hasil ini tidak konsisten dengan penelitian yang dilakukan oleh Damarjati et al (2018). Hal ini dikarenakan perusahaan umumnya telah mempunyai manajemen kas yang baik. Cash holding menjadi peranan penting dan menjadi salah satu pusat perhatian dan pengawasan dalam menunjang aktivitas perusahaan. Untuk mengembangkan usahanya atau bisnis, suatu perusahaan biasanya memiliki manajemen kas yang baik. Setiap perusahaan berusaha untuk menyediakan uang kas dalam jumlah yang ideal. Artinya tidak terlalu banyak dan tidak terlalu sedikit, yang 
dapat menurunkan efisiensi akibat tertanamnya uang dalam kas yang sebenarnya tidak produktif. Apabila kas yang dimiliki perusahaan terlalu sedikit maka aktivitas perusahaan tidak dapat berjalan dengan baik. Penentuan tingkat cash holding merupakan keputusan penting yang harus diambil oleh manajer.

\section{Pengaruh Debt Maturity terhadap kinerja keuangan}

Hipotesis keempat $(\mathrm{H} 4)$ dalam penelitian ini adalah debt maturity berpengaruh positif terhadap kinerja keuangan perusahaan. Berdasarkan hasil penelitian pada perusahaan property dan real estate yang terdaftar di BEI pada tahun 2014-2018, ditemukan bahwa hipotesis (H4) ditolak, hal ini menunjukkan bahwa debt maturity tidak berpengaruh terhadap kinerja keuangan. Hal ini dapat dilihat dari hasil regresi panel pada tabel 8 dimana, diperoleh koefisien regresi debt maturity 0,0938 dan juga menunjukkan nilai signifikan variabel $\beta_{4} \mathrm{X}_{4}$ lebih besar dari $\alpha 5 \%$, yaitu $0,0744>5 \%$ serta, t-hitung $<$ t-tabel yaitu, 1,8044 $<2,080$. Sehingga dapat disimpulkan bahwa debt maturity tidak berpengaruh terhadap kinerja keuangan.

Pada penelitian ini debt maturity yang diproksikan dengan jumlah utang jangka pendek. Hasil penelitian ini konsisten dengan penelitian yang dilakukan oleh Sufiyati (2016) menyatakan bahwa short term debt (utang jangka pendek) tidak memiliki pengaruh terhadap kinerja keuangan. Tidak adanya pengaruh utang jangka pendek terhadap kinerja keuangan disebabkan oleh utang jangka pendek memiliki pengaruh yang kecil terhadap laba. Salah satu utang jangka pendek yang berbunga rendah adalah utang usaha, dan pada umumnya perusahaan property dan real estate memiliki utang usaha yang besar. Rendahnya tingkat utang jangka pendek yang dibayarkan oleh perusahaan dapat dilihat dari tingkat bunga utang jangka pendek pada laporan keuangan. Namun hasil penelitian yang berbeda yang dilakukan oleh Maulana dan Safa (2017) dan Damarjati et al (2018) bahwa debt maturity berpengaruh terhadap kinerja keuangan perusahaan.

\section{SIMPULAN, KETERBATASAN DAN SARAN Kesimpulan}

Berdasarkan hasil penelitian dapat disimpulkan penelitian ini bertujuan untuk mengetahui faktorfaktor yang mempengaruhi kinerja keuangan pada perusahaan property dan real estate yang terdaftar pada BEI tahun 2014 sampai 2018. Berdasarkan hasil analisis dan pembahasan yang telah dilakukan terhadap empat hipotesis yang telah diuji dengan menggunakan analisis linear berganda, maka dapat ditarik kesimpulan bahwa kepemilikan asing, cash holding dan debt maturity tidak berpengaruh terhadap kinerja keuangan pada perusahaan property dan real estate yang terdaftar di BEI tahun 2014-2018, hanya leverage yang memiliki pengaruh negatif dan signifikan terhadap kinerja keuangan perusahaan property dan real estate yang terdaftar di BEI tahun 2014-2018.

\section{Keterbatasan}

Peneliti telah berusaha merancang dan mengembangkan penelitian sedemikian rupa, namun masih terdapat beberapa keterbatasan dalam penelitian ini yang masih perlu diperbaiki bagi peneliti selanjutnya, yaitu antara lain:

1. Penelitian ini baru menggambarkan pada potret perusahaan property dan real estate, sehingga data penelitian tidak dapat mewakili keseluruhan perusahaan pada BEI.

2. Tahun pengamatan yang digunakan dalam pengambilan sampel hanya mencakup 5 tahun yaitu dari tahun 2014-2018. Hal ini dikarenakan keterbatasan informasi dan keterbatasan data yang tidak lengkap. 
3. Tidak semua sampel menyajikan data informasi yang dibutuhkan oleh peneliti contohnya kepemilikan asing, tidak semua perusahaan yang mempunyai kepemilikan asing sehingga sampel pada penelitian ini cukup minim hanya 24 perusahaan.

\section{Saran}

Berdasarkan kesimpulan dari hasil penelitian yang telah dijelaskan diatas saran yang dapat diberikan. Bagi perusahaan diharapkan perusahaan lebih memperhatikan faktor faktor yang dapat meningkatkan kinerja keuangan agar perusahaan yang memiliki kinerja yang buruk lebih memperhatikan dan meningkatkan kinerja keuangannya agar nantinya dapat meningkatkan keinginan/minat investor dalam halnya investasi karena perusahaan mempunyai kinerja yang baik.

Bagi penelitian selanjutnya diharapkan dapat menggunakan jenis perusahaan yang berbeda-beda dan memakai ruang lingkup sampel yang lebih luas, dapat menambah tahun pengamatan dengan meneliti lebih dari 5 tahun agar hasil yang diperoleh lebih berkualitas, agar menggunakan sampel yang menyajikan semua elemen data yang dibutuhkan guna pengukuran kepemilikan asing, dan sebaiknya mempertimbangkan dan mencari variabel independen lainnya yang berhubungan dengan kinerja keuangan perusahaan.

\section{DAFTAR PUSTAKA}

Abadi, S. (2013). Faktor- Faktor yang Mempengaruhi Debt Maturity di Sektor Industri Manufaktur yang Terdaftar di Bursa Efek Indonesia Tahun 2008-2012. 2(2), 1-10.

Admaja. A. A. (2016). Pengaruh Kepemilikan Asing dan Corporate Social Responsibility terhadap Kinerja Keuangan Perusahaan yang Terdaftar dalam Index Sri-Kehati Tahun 2009 - 2013. Program Studi Manajemen Fakultas Ekonomi Universitas Atma Jaya Yogyakarta Jalan Babarsari 43044, Yogyakarta.

Anthony, R., \& Vijay, G. (2009). Management Control System-Sistem Pengendalian Manajemen. Buku 2. Edisi Sebelas. Alih Bahasa: Kurinawan \& Krista. Jakarta: Salemba Empat.

Athur J. Keown. (2010). Manajemen Keuangan. Edisi Sepuluh. Jakarta: PT. Macanan Jaya Cemerlang.

Azis, A. (2017). Pengaruh Good Corporate Governance, Struktur Modal, dan Leverage terhadap Kinerja Keuangan Perusahaan Pada Sektor Pertambangan yang Terdaftar di BEI Tahun 2011-2015. Jurnal Ilmu Manajemen (JIM), 5(3).

Azzahra, A. S., \& Nasib. (2019). Pengaruh Firm Size Dan Leverage Ratio Terhadap Kinerja Keuangan pada Perusahaan. Jwem Stie Mikroskil, 9(April), 13-20.

Balagobei, S., \& Velnampy, T. (2017). A Study on Ownership Structure and Financial Performance of Listed Beverage Food and Tobacco Companies in Sri Lanka. International Journal of Accounting and Financial Reporting, 7(2), 36. https://doi.org/10.5296/ijafr.v7i2.11518 
Brigham, Eugene. F dan Joel F. Houston. (2001). Manajemen Keuangan, Edisi Kedelapan Buku 2. Jakarta: Erlangga.

Damarjati, A., Akuntansi, D., Ekonomika, F., Diponegoro, U., Prof, J., \& Sh, S. (2018). Pengaruh Leverage, Debt Maturity, Kebijakan Deviden, dan Cash Holding terhadap Kinerja Keuangan Perusahaan ( Studi Pada Perusahaan Manufaktur yang Terdaftar Di BEI tahun 2017 ). 7, 1-12.

Dewi, Rosiana \& Lestari, H, S. (2016). Pengaruh Financial Leverage Terhadap Kinerja Keuangan (Studi Pada Perusahaan Manufaktur yang Terdaftar di Bursa Efek Indonesia Periode 2009-2013). Jurnal Riset Bisnis Dan Investasi, 11(1). https://doi.org/10.35697/jrbi.v3i3.944

Enekwe, C., Ikechukwu, Agu, C., \& Nnagbogu, E. K. (2014). The Effect of Financial Leverage on Financial Performance: Evidence of Quoted Pharmaceutical Companies in Nigeria. IOSR Journal of Economics and Finance, 5(3), 17-25. https://doi.org/10.9790/5933-0531725

Fahmi, I. (2012). Analisis Kinerja Keuangan (Buku Satu). Bandung: Alfabeta.

Fahmi, I. (2014). Analisis Laporan Keuangan. Alfabeta. Bandung: Alfabeta

García-Teruel, P. J., Martinez-Solano, P., \& Sanchez-Ballesta, J. P. (2009). Accruals quality and corporate cash holdings. Accounting and Finance, 49(1), 95-115. https://doi.org/10.1111/j.1467-629X.2008.00276.x

Ghozali. (n.d.). Aplikasi Analisis Multivariate dengan Program IBM SPSS 23, Edisi 8.

Gill, A. S. (2012). Determinants of Corporate Cash Holdings : Evidence from Canada. 4(1), 7079. https://doi.org/10.5539/ijef.v4n1p70

Graham, J. R., \& Harvey, C. R. (2001). The Theory and Practice of Corporate Finance: Evidence from the Field. Journal of Financial Economics, 60(2-3), 187-243. https://doi.org/10.1016/S0304-405X(01)00044-7

Hermiyetti, \& Katlanis, E. (2016). Analisis Pengaruh Kepemilikan Manajerial, Kepemilikan Institusional, Kepemilikan Asing, Dan Komite Audit Terhadap Kinerja Keuangan Perusahaan. Media Riset Akuntansi, 6(2), 25-43.

Ifada, M. L., \& Inayah, N. (2017). Analisis Pengaruh Tingkat Leverage terhadap Kinerja Perusahaan. ( Studi pada Perusahaan Food and Beverage yang Terdaftar di BEI Tahun 2011-2013 ) Fokus Ekonomi. Fokus Ekonomi, 12(1), 19-36. https://doi.org/https://doi.org/10.34152/fe.12.1.19-36

Jun, S., \& Jen, F. C. (2003). Trade-off Model of Debt Maturity Structure. 1977, 5-34.

Kasmir. (2010). Pengantar Manajemen Keuangan. Edisi Kedua. Jakarta: Kencana. 
Kusuma, Arya, R. (2018). Pengaruh Financial Leverage terhadap Profitabilitas (Studi pada Perusahaan Property \& Real Estate yang terdaftar di BEI 2013-1015. Journal Administrasi Bisnis, 65 No 1.

Martinez-Sola, C., Garcia-Teruel, P. J., \& Martinez-Solano, P. (2013). Corporate cash holding and firm value. Applied Economics, 45(2), 161-170. https://doi.org/10.1080/00036846.2011.595696

Myers, C. (1977). Determinants of Corporate Stewart C. 5, 147-175.

Nopitasari, H., Tiorida, E., \& Sarah, I. S. (2018). Pengaruh Financial Leverage Terhadap Kinerja Keuangan (Studi Pada Perusahaan Properti dan Real Estate yang Terdaftar di Bursa Efek Indonesia Periode 2011-2015). Jurnal Riset Bisnis Dan Investasi, 3(3), 45. https://doi.org/10.35697/jrbi.v3i3.944

Nugrahawati, Selviana. (2019). Pengaruh Struktur Kepemilikan dan Ukuran Perusahaan terhadap Kinerja Keuangan (ROA). Studi Empiris Perusahaan Manufaktur yang Terdaftar di BEI Tahun 2014-2016. Jurnal Akuntansi dan Bisnis.

Opler, T., Pinkowitz, L., Stulz, R., \& Williamson, R. (1999). The Determinants and Implications of Corporate Cash Holdings. Journal of Financial Economics, 52(1), 3-46. https://doi.org/10.1016/s0304-405x(99)00003-3

Palazzo, D. Wang, N. (2011). Cash holdings, risk, and expected returns for their guidance and encouragement. I also thank an anonymous referee.

Pangaribuan, Rubenta Christinauli. (2017). Pengaruh Struktur Kepemilikan dan Struktur Pengelolaan terhadap Kinerja Keuangan Pada perusahaan Property dan Real Estate yang Terdaftar di BEI 2014 - 2016. http://lib.ibs.ac.id

Pratiwi, Monica, W. (2017). Analisis Faktor-Faktor yang Mempengaruhi Kinerja Keuangan Perusahaan. Jurnal Media Ekonomi Dan Manajemen, 32 No 1.

Rudianto. (2013). Akuntansi Manajemen Informasi untuk Pengambilan Keputusan Strategis. Erlangga.

Siregar Hasrul, Rahayu Dessy. (2017). Corporate Governance dan Kinerja. Jurnal Akuntansi , Ekonomi Dan Manajemen Bisnis ISSN : 2337-7887, 2(2), 121-131.

Stice, E. k, \& James D. Stice \&. (2007). Akuntansi Keuangan. Buku 1. Edisi 16. CPA: Salemba Empat.

Sulastri, A., Puspa, D. F., \& Fauziati, P. (2016). Pengaruh Leverage, Size Perusahaan dan Kinerja Lingkungan terhadap Kinerja Keuangan Perusahaan yang Terdaftar Di Bursa Efek Indonesia (Bei). Jurnal Fakultas Ekonomi, 8(1), 1-11. http://ejurnal.bunghatta.ac.id/index.php?journal=JFEK\&page 
Suwardjono. (2012). Teori Akuntansi, Perekayasaan Pelaporan Keuangan. Yogyakarta: BPFE

Tong, Z. (2006). Risk Reduction as a CEO's Motive for Corporate Cash Holdings Risk Reduction as a CEO's Motive for Corporate Cash Holdings. 1-46.

Triwacananingrum, W., \& Hidayat, W. (2014). Pengaruh Kinerja Sosial Dan Financial Leverage Terhadap Kinerja Keuangan Dengan Klasifikasi Perusahaan Sebagai Variabel Moderator pada Bumn Yang Terdaftar Di Bei Periode Tahun 2008-2012. Agustus, 2, 150-158.

Ulfiyati, U., Lambey, L., \& Walandouw, S. K. (2017). Analisis Perbedaan Struktur Kepemilikan Asing Dan Struktur Kepemilikan Domestik Pada Perusahaan Pertambangan Di Bursa Efek Indonesia. Jurnal EMBA: Jurnal Riset Ekonomi, Manajemen, Bisnis Dan Akuntansi, 5(2), $2260-2267$.

Undang-Undang Republik Indonesia Nomor 25 Tahun 2007 Tentang Penanaman Modal.

Vijayakumaran, R., \& Atchyuthan, N. (2017). Cash holdings and corporate performance: Evidence from Sri Lanka Ratnam Vijayakumaran and Nagajeyakumarn Atchyuthan. Www.Researchgate.Net/Publication/319290974 Cash, 1.

Warmana, G. O., \& Widnyana, I. W. (2017). Pengaruh Keputusan Pendanaan terhadap Kinerja Keuangan Perusahaan pada Sektor Pariwisata, Restoran dan Hotel. 12(2), 163-170.

Yavas, C. V., \& Erdogan, S. B. (2017). The Effect of Foreign Ownership on Firm Performance: Evidence from Emerging Market. Australian Academy of Accounting and Finance Review, 2(4), 363-371. 